\title{
LEVEL II SCOUR ANALYSIS FOR BRIDGE 33 (BETHTH00310033) on TOWN HIGHWAY 31, crossing LILLIESVILLE BROOK, BETHEL, VERMONT
}

U.S. Geological Survey Open-File Report 96-191

Prepared in cooperation with

VERMONT AGENCY OF TRANSPORTATION and

FEDERAL HIGHWAY ADMINISTRATION 


\section{LEVEL II SCOUR ANALYSIS FOR BRIDGE 33 (BETHTH00310033) on TOWN HIGHWAY 31, crossing LILLIESVILLE BROOK, BETHEL,}

\section{VERMONT}

By MICHAEL A. IVANOFF and ROBERT E. HAMMOND

U.S. Geological Survey Open-File Report 96-191

Prepared in cooperation with

VERMONT AGENCY OF TRANSPORTATION

and

FEDERAL HIGHWAY ADMINISTRATION 


\title{
U.S. DEPARTMENT OF THE INTERIOR BRUCE BABBITT, Secretary
}

\author{
U.S. GEOLOGICAL SURVEY \\ Gordon P. Eaton, Director
}

For additional information write to:

District Chief

U.S. Geological Survey 361 Commerce Way

Pembroke, NH 03275-3718
Copies of this report may be purchased from:

U.S. Geological Survey Earth Science Information Center Open-File Reports Section Box 25286, MS 517 Federal Center

Denver, CO 80225 


\section{CONTENTS}

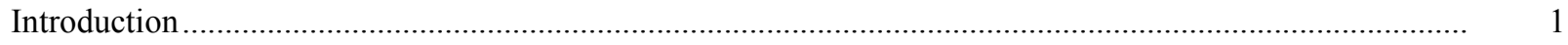

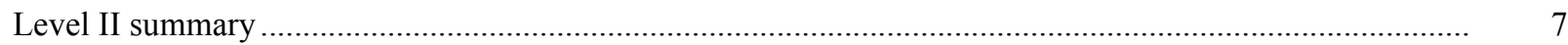

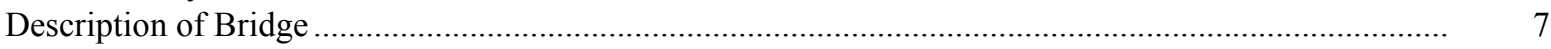

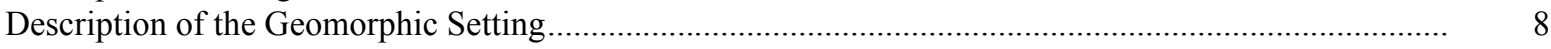

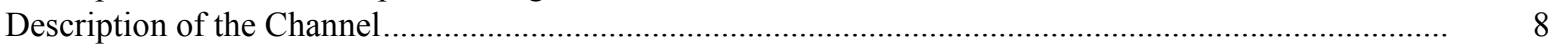

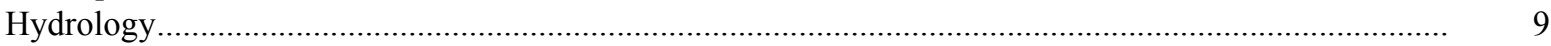

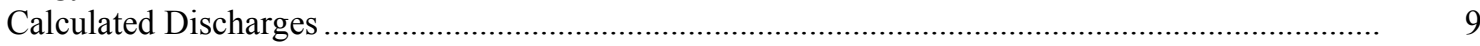

Description of the Water-Surface Profile Model (WSPRO) Analysis ......................................................... 10

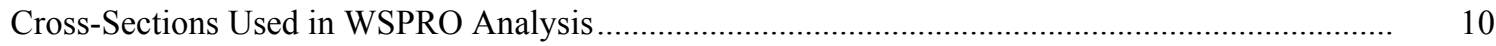

Data and Assumptions Used in WSPRO Model ...........................................................................

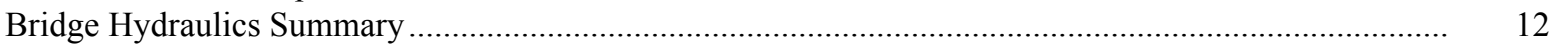

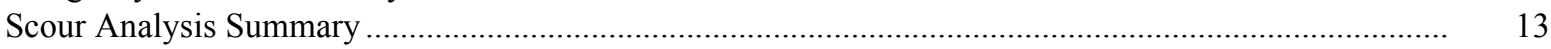

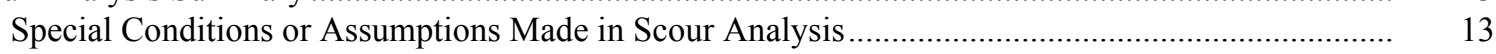

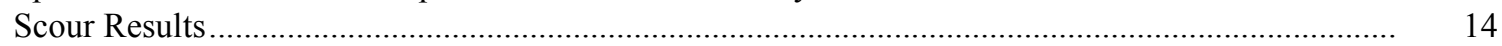

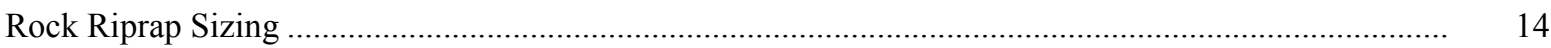

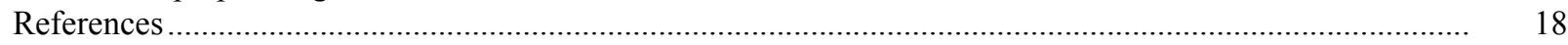

Appendixes:

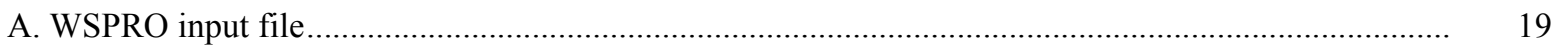

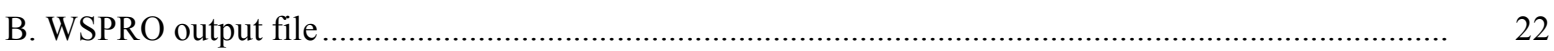

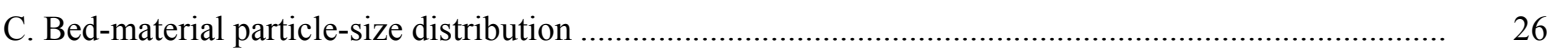

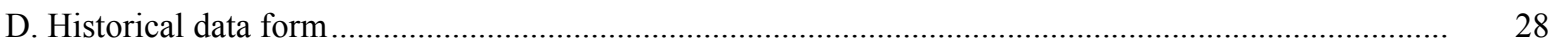

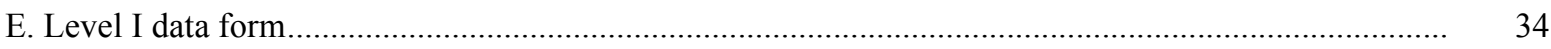

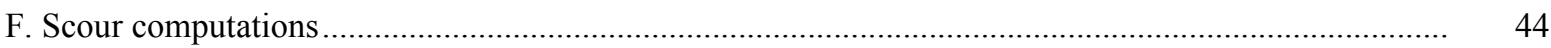

\section{FIGURES}

1. Map showing location of study area on USGS 1:24,000 scale map ........................................................

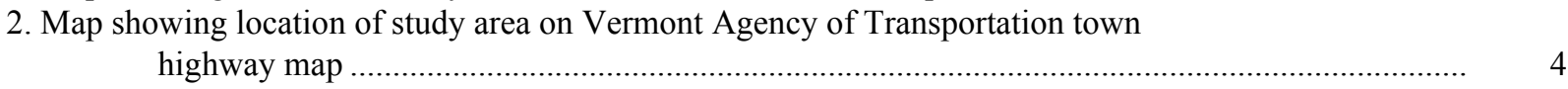

3. Structure BETHTH00310033 viewed from upstream (October 13, 1994) ................................................. 5

4. Downstream channel viewed from structure BETHTH00310033 (October 13, 1994)............................. 5

5. Upstream channel viewed from structure BETHTH00310033 (October 13, 1994)..................................... 6

6. Structure BETHTH00310033 viewed from downstream (October 13, 1994)............................................ 6

7. Water-surface profiles for the 100- and 500-year discharges at structure

BETHTH00310033 on Town Highway 31, crossing Lilliesville Brook, Bethel, Vermont.

8. Scour elevations for the 100- and 500-year discharges at structure

BETHTH00310033 on Town Highway 31, crossing Lilliesville Brook,

Bethel, Vermont.

\section{TABLES}

1. Remaining footing/pile depth at abutments for the 100-year discharge at structure BETHTH00310033 on Town Highway 31, crossing Lilliesville Brook, Bethel, Vermont

2. Remaining footing/pile depth at abutments for the 500-year discharge at structure

BETHTH00310033 on Town Highway 31, crossing Lilliesville Brook,

Bethel, Vermont 


\begin{tabular}{|c|c|c|}
\hline Multiply & By & To obtain \\
\hline \multicolumn{3}{|c|}{ Length } \\
\hline inch (in.) & 25.4 & millimeter (mm) \\
\hline foot $(\mathrm{ft})$ & 0.3048 & meter $(\mathrm{m})$ \\
\hline mile (mi) & 1.609 & kilometer (km) \\
\hline \multicolumn{3}{|c|}{ Slope } \\
\hline foot per mile ( $\mathrm{ft} / \mathrm{mi})$ & 0.1894 & meter per kilometer $(\mathrm{m} / \mathrm{km})$ \\
\hline \multicolumn{3}{|c|}{ Area } \\
\hline square mile $\left(\mathrm{mi}^{2}\right)$ & 2.590 & square kilometer $\left(\mathrm{km}^{2}\right)$ \\
\hline \multicolumn{3}{|c|}{ Volume } \\
\hline cubic foot $\left(\mathrm{ft}^{3}\right)$ & 0.02832 & cubic meter $\left(\mathrm{m}^{3}\right)$ \\
\hline \multicolumn{3}{|c|}{ Velocity and Flow } \\
\hline foot per second $(\mathrm{ft} / \mathrm{s})$ & 0.3048 & meter per second $(\mathrm{m} / \mathrm{s})$ \\
\hline cubic foot per second $\left(\mathrm{ft}^{3} / \mathrm{s}\right)$ & 0.02832 & cubic meter per second $\left(\mathrm{m}^{3} / \mathrm{s}\right.$ \\
\hline cubic foot per second per & 0.01093 & cubic meter per \\
\hline square mile & & second per square \\
\hline$\left[\left(\mathrm{ft}^{3} / \mathrm{s}\right) / \mathrm{mi}^{2}\right]$ & & kilometer $\left[\left(\mathrm{m}^{3} / \mathrm{s}\right) / \mathrm{km}^{2}\right]$ \\
\hline
\end{tabular}

OTHER ABBREVIATIONS

\begin{tabular}{|c|c|c|c|}
\hline $\mathrm{BF}$ & bank full & LWW & left wingwall \\
\hline $\mathrm{cfs}$ & cubic feet per second & $\mathrm{MC}$ & main channel \\
\hline $\mathrm{D}_{50}$ & median diameter of bed material & RAB & right abutment \\
\hline DS & downstream & RABUT & face of right abutment \\
\hline elev. & elevation & $\mathrm{RB}$ & right bank \\
\hline $\mathrm{f} / \mathrm{p}$ & flood plain & ROB & right overbank \\
\hline $\mathrm{ft}^{2}$ & square feet & RWW & right wingwall \\
\hline $\mathrm{ft} / \mathrm{ft}$ & feet per foot & $\mathrm{TH}$ & town highway \\
\hline JCT & junction & UB & under bridge \\
\hline LAB & left abutment & US & upstream \\
\hline LABUT & face of left abutment & USGS & United States Geological Survey \\
\hline LB & left bank & VTAOT & Vermont Agency of Transportation \\
\hline LOB & left overbank & WSPRO & water-surface profile model \\
\hline
\end{tabular}

In this report, the words "right" and "left" refer to directions that would be reported by an observer facing downstream.

Sea level: In this report, "sea level" refers to the National Geodetic Vertical Datum of 1929-- a geodetic datum derived from a general adjustment of the first-order level nets of the United States and Canada, formerly called Sea Level Datum of 1929. 


\title{
LEVEL II SCOUR ANALYSIS FOR BRIDGE 33 (BETHTH00310033) ON TOWN HIGHWAY 31, CROSSING LILLIESVILLE BROOK, BETHEL, VERMONT
}

\author{
By Michael A. Ivanoff and Robert E. Hammond
}

\section{INTRODUCTION}

This report provides the results of a detailed Level II analysis of scour potential at structure BETHTH00310033 on town highway 31 crossing the Lilliesville Brook, Bethel, Vermont (figures 1-8). A Level II study is a basic engineering analysis of the site, including a quantitative analysis of stream stability and scour (U.S. Department of Transportation, 1993). A Level I study is included in Appendix E of this report. A Level I study provides a qualitative geomorphic characterization of the study site. Information on the bridge available from VTAOT files was compiled prior to conducting Level I and Level II analyses and can be found in Appendix D.

The site is in the Green Mountain physiographic province of central Vermont in the town of Bethel. The $6.85-\mathrm{mi}^{2}$ drainage area is in a predominantly rural and forested basin. In the vicinity of the study site, the left banks have shrub and brush, and the right banks are forested.

In the study area, Lilliesville Brook has an incised, straight channel with a slope of approximately $0.02 \mathrm{ft} / \mathrm{ft}$, an average channel top width of $37 \mathrm{ft}$ and an average channel depth of $4 \mathrm{ft}$. The predominant channel bed material is gravel and cobble $\left(\mathrm{D}_{50}\right.$ is $66.8 \mathrm{~mm}$ or $0.219 \mathrm{ft}$ ). The geomorphic assessment at the time of the Level I and Level II site visit on October 13 and 14, 1994, indicated that the reach was stable. 
The town highway 31 crossing of Lilliesville Brook is a 41-ft-long, one-lane bridge consisting of one 39-foot steel-beam span with a timber deck (Vermont Agency of Transportation, written commun., August 24, 1994). The bridge is supported by vertical, concrete abutments with wingwalls. The channel is skewed approximately 35 degrees to the opening while the opening-skew-to-roadway is 0 degrees.

Scour protection measures in place at the site were type- 1 stone fill (less than 12 inches diameter) at the downstream left wingwall, left abutment, and upstream and downstream sides of the left road embankment. Additional details describing conditions at the site are included in the Level II Summary and Appendices D

and $\mathrm{E}$.

Scour depths and rock rip-rap sizes were computed using the general guidelines described in Hydraulic Engineering Circular 18 (Richardson and others, 1993). Scour depths were calculated assuming an infinite depth of erosive material and a homogeneous particle-size distribution. The scour analysis results are presented in tables 1 and 2 and a graph of the scour depths is presented in figure 8. 


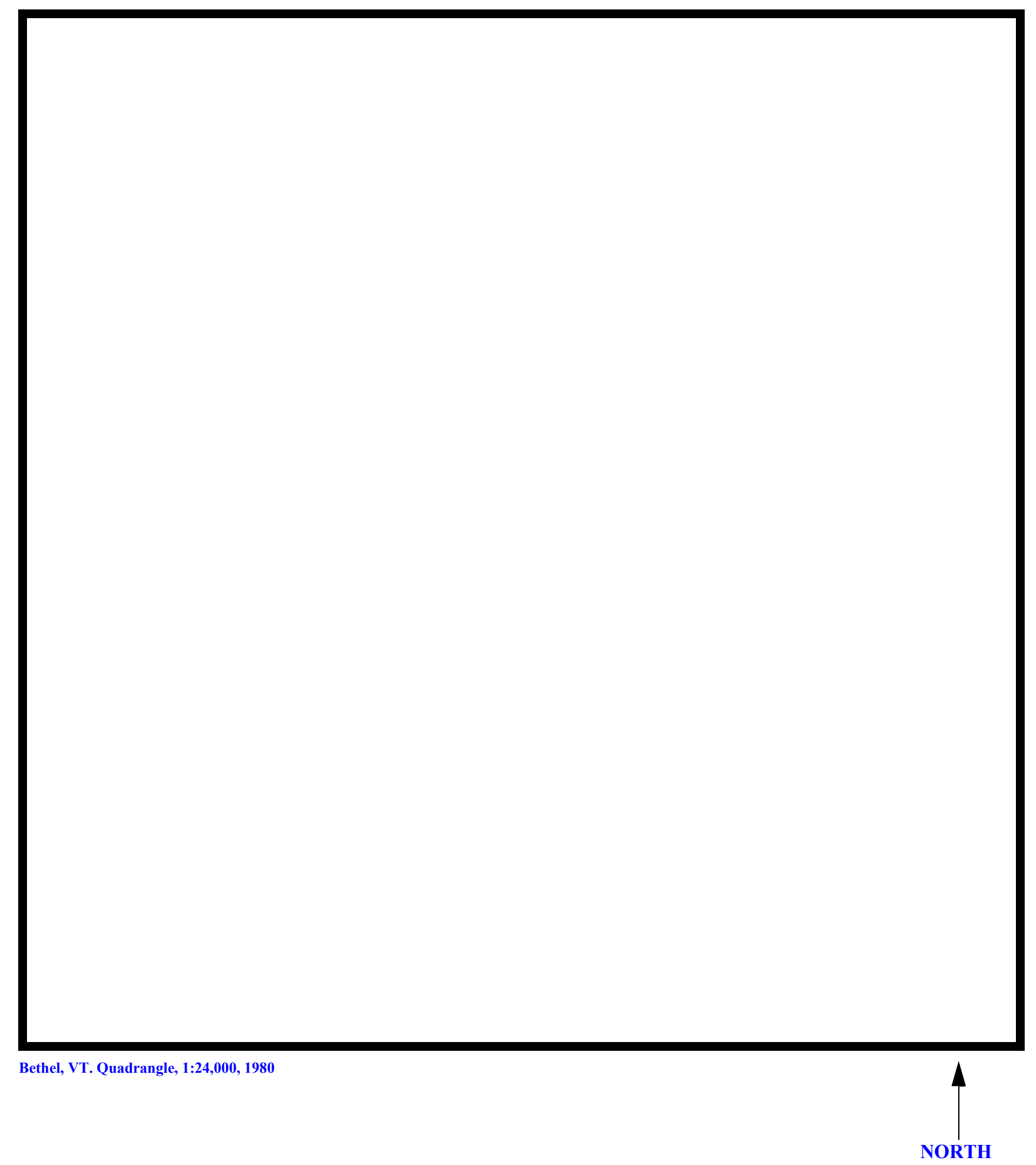

Figure 1. Location of study area on USGS 1:24,000 scale map. 
Figure 2. Location of study area on Vermont Agency of Transportation town highway map. 

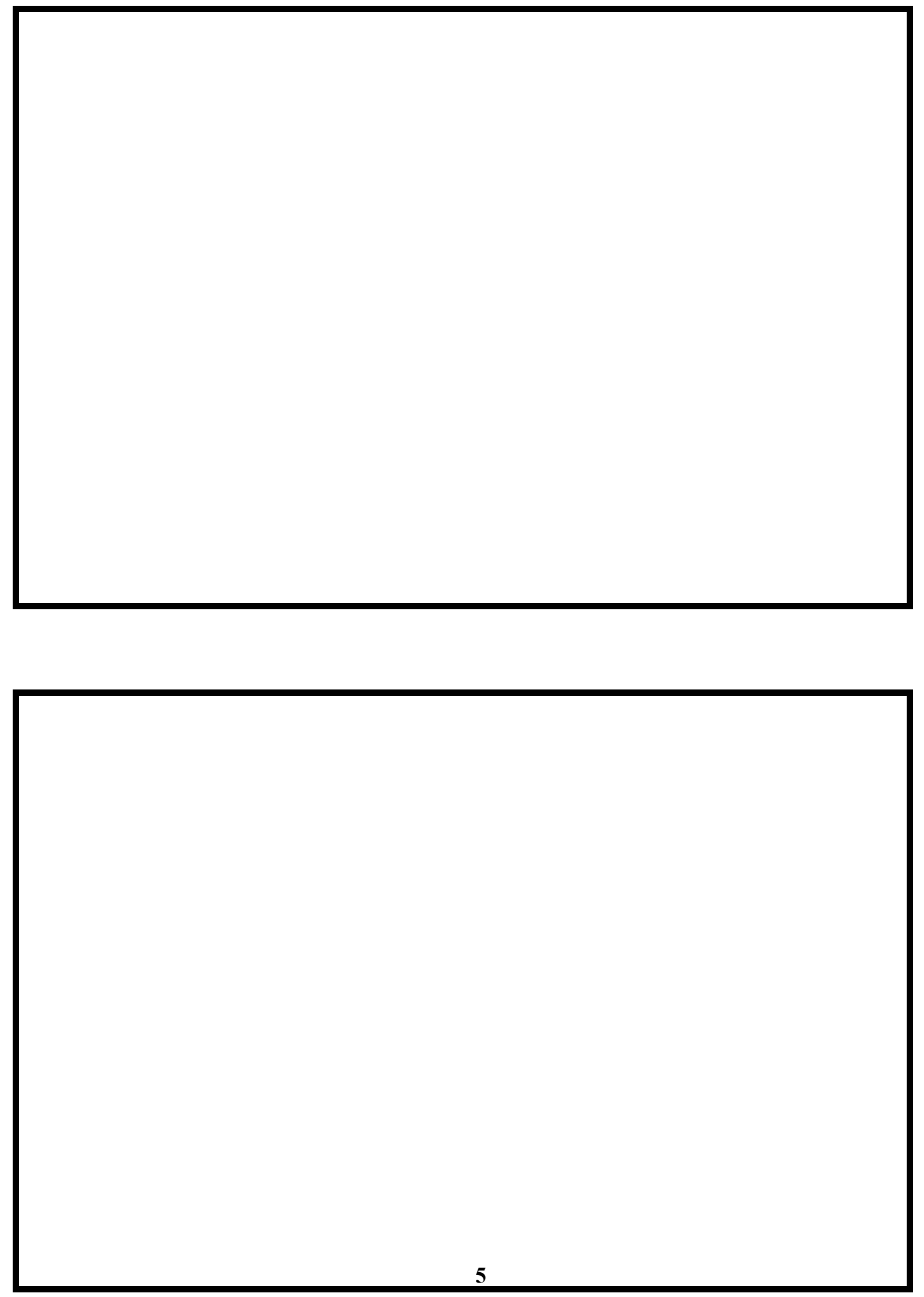

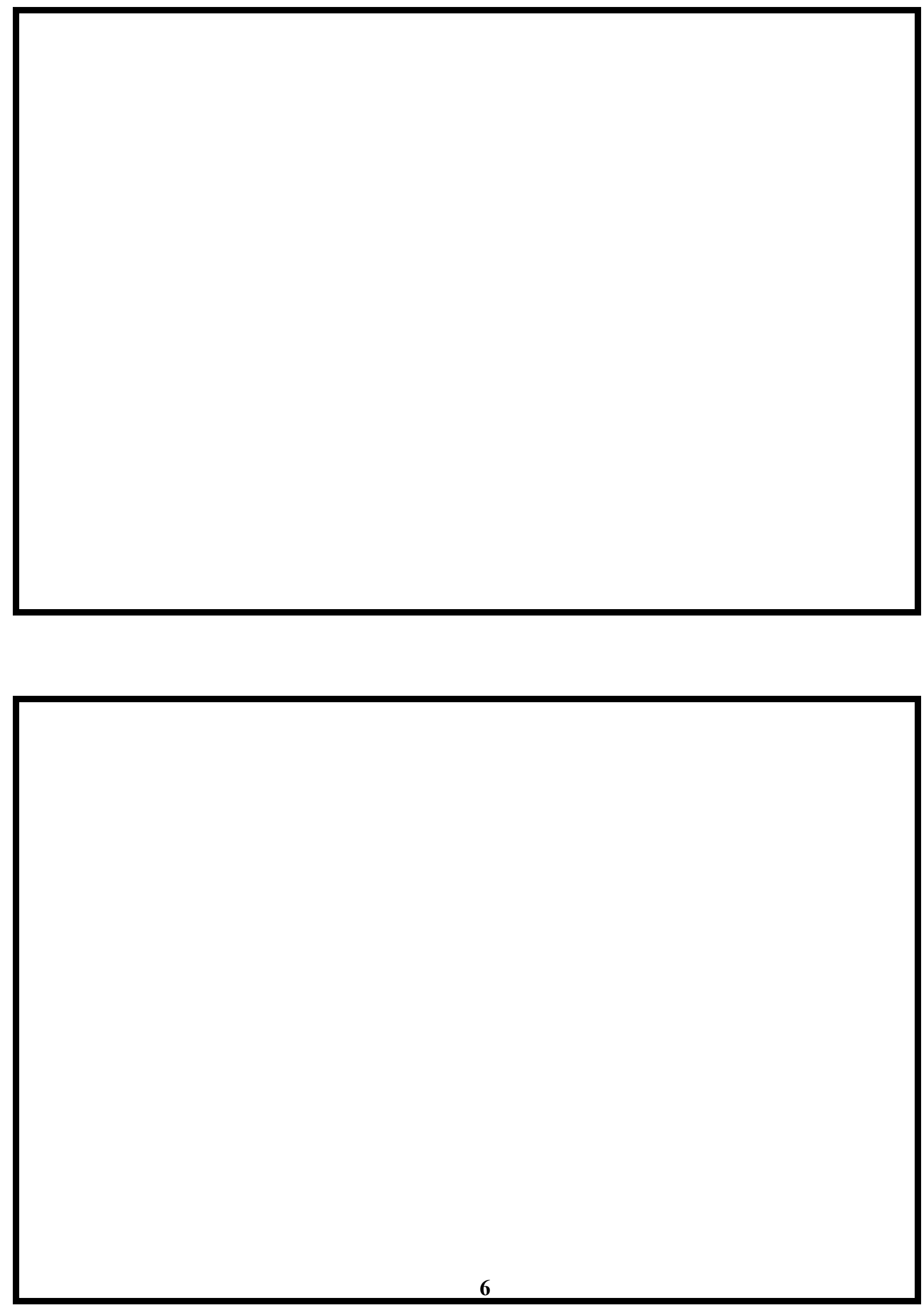


\section{LEVEL II SUMMARY}

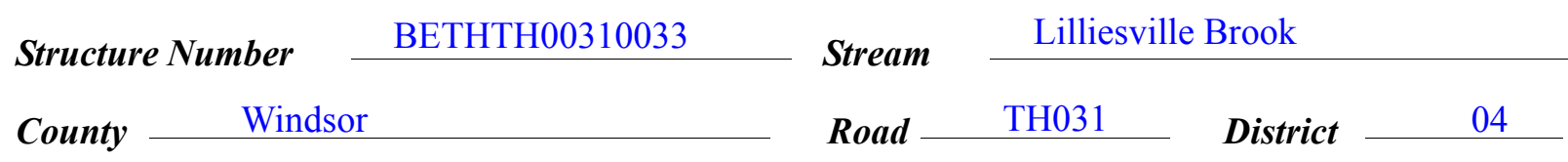

\section{Description of Bridge}

\begin{tabular}{|c|c|c|c|}
\hline Bridge length & Bridge width & 14.0 & \multirow{2}{*}{ Max span length } \\
\hline \multirow{2}{*}{\multicolumn{3}{|c|}{ Alignment of bridge to road (on curve or straight) }} & \\
\hline \multirow{2}{*}{ Abutment type } & & \multirow{2}{*}{ Embankment type } & N/A \\
\hline & Yes & & $10 / 14 / 94$ \\
\hline \multicolumn{4}{|c|}{$\begin{array}{ll}\text { Stone fill on abutment? } & \text { Mato nf insnortion } \\
\text { Type-1, around the downstream left wingwall, left abutment, and }\end{array}$} \\
\hline
\end{tabular}

Concrete abutments and wingwalls. The left abutment

is 5 degrees from vertical and the right abutment is 10 degrees from vertical.

\begin{tabular}{lll}
\hline & $\mathrm{Y}$ & 35 \\
Is bridge skewed to flood flow according to $\mathrm{Y} \quad$ 'survey? & Angle \\
There is a moderate bend in the channel upstream of its approach to the bridge. &
\end{tabular}

Debris accumulation on bridge at time of Level I or Level II site visit:

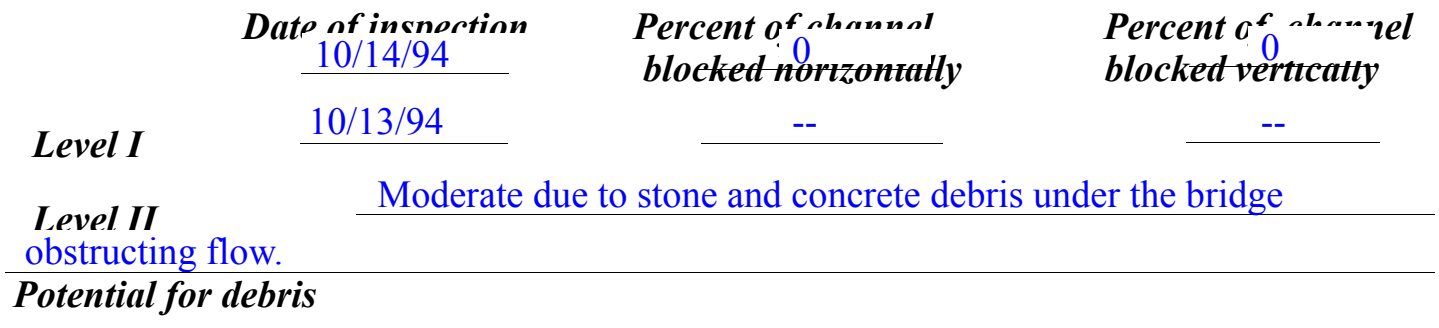

10/14/94 - There is a stone and concrete debris pile under the bridge.

Doscriho any foaturos noar ar at tho hridos that mav' affort flow, (includo ahsorvation dato) 


\section{Description of the Geomorphic Setting}

General topography The channel has a flat to slightly irregular flood plain with steep valley

walls on both sides.

Geomorphic conditions at bridge site: downstream (DS), upstream (US)

Date of inspection $\quad 10 / 14 / 94$

DS left: $\quad$ Steep channel bank to a terrace

DS right: $\quad$ Steep channel bank to a narrow terrace

US left: $\quad$ Steep channel bank to a narrow terrace

US right: $\quad$ Steep valley wall

\section{Description of the Channel}

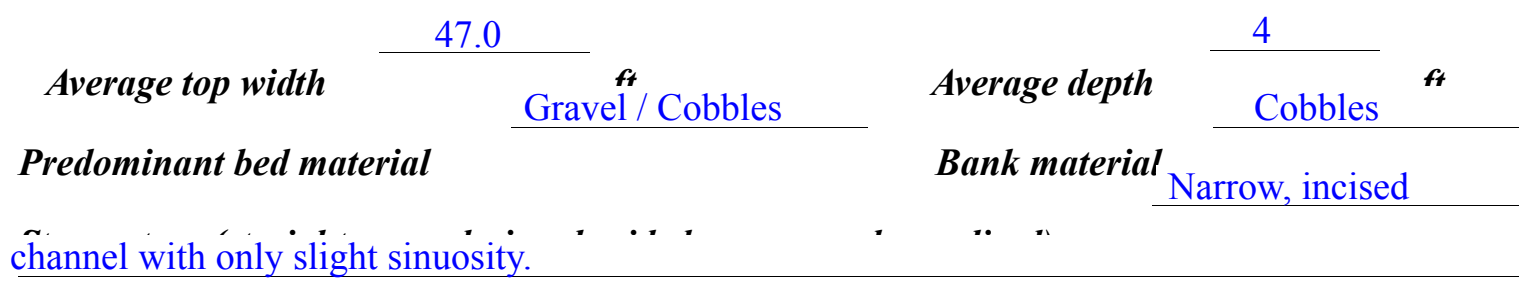

Vegetative co ${ }^{1}$ shrub and brushland

DS left: $\quad$ forested with town highway 31 on the terrace

DS right: $\quad$ shrub and brushland with town highway 31 on the terrace

US left: $\quad$ forested

US right: $\quad \underline{\mathrm{Y}}$

Do banks appear stable? 10/14/94 -- Assessed as stable, however slight fluvial erosion noted on both upstream banks. Also, a cut bank and point bar were noted upstream. See appendix E for
date of observatton. more details.

concrete debris near mid-channel under the bridge. Describe any obstructions in channel and date of observation. 


\section{Hydrology}

Drainage area $\quad 6.85 \boldsymbol{m i}^{2}$

Percentage of drainage area in physiographic provinces: (approximate)

Physiographic province

Green Mountain
Percent of drainage area

100

Is drainage area considered rural or urban? Rural Describe any significant urbanization:

Area is primarily forested.

Is there a USGS gage on the stream of interest?

No

\section{USGS gage description}

USGS gage number

Gage drainage area

$m i^{2}$

No

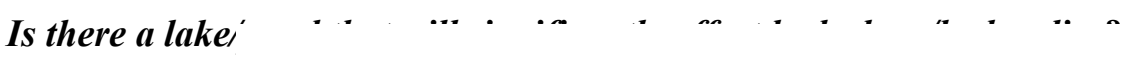

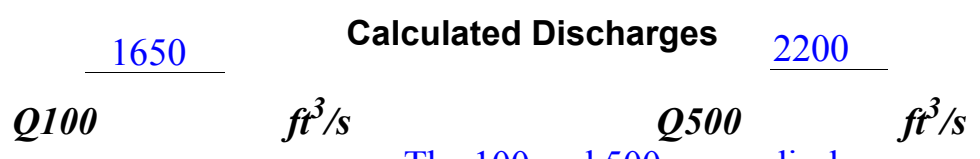

The 100 and 500 - year discharges were computed

from an area relationship with a downstream site which has a drainage area of $7.1 \mathrm{mi}^{2}[(6.85 /$

$\left.7.1)^{0.7}\right]$. The flood frequency estimates for the downstream site were available from the VTAOT database (VTAOT written commun. 1995). 


\section{Description of the Water-Surface Profile Model (WSPRO) Analysis}

Datum for WSPRO analysis (USGS survey, sea level, VTAOT plans)

USGS survey

Datum tie between USGS survey and VTAOT plans

None

Description of reference marks used to determine USGS datum. $\quad$ RM1 is a chiseled X on

top of the US end of the right abutment (elev. $498.54 \mathrm{ft}$, arbitrary datum). RM2 is a chiseled X

on top of the DS end of the left abutment (elev. $498.74 \mathrm{ft}$, arbitrary datum).

\section{Cross-Sections Used in WSPRO Analysis}

\begin{tabular}{|c|c|c|c|}
\hline${ }^{1}$ Cross-section & $\begin{array}{c}\text { Section } \\
\text { Reference } \\
\text { Distance } \\
\text { (SRD) in feet }\end{array}$ & $\begin{array}{c}{ }^{2} \text { Cross-section } \\
\text { development }\end{array}$ & Comments \\
\hline EXITX & -62 & 1 & Exit section \\
\hline FULLV & 0 & 2 & $\begin{array}{l}\text { Downstream Full-valley } \\
\text { section (Templated from } \\
\text { EXITX) }\end{array}$ \\
\hline BRIDG & 0 & 1 & Bridge section \\
\hline RDWAY & 9 & 1 & Road Grade section \\
\hline APPRO & 57 & 1 & Approach section \\
\hline
\end{tabular}

${ }^{1}$ For location of cross-sections see plan-view sketch included with Level I field form, Appendix E. For more detail on how cross-sections were developed see WSPRO input file. 


\section{Data and Assumptions Used in WSPRO Model}

Hydraulic analyses of the reach were done by use of the Federal Highway Administration's WSPRO step-backwater computer program (Shearman and others, 1986, and

Shearman, 1990). Results of the hydraulic model are presented in the Bridge Hydraulic Summary, Appendix B, and figure 7.

Channel roughness factors (Manning's " $\mathrm{n}$ ") used in the hydraulic model were estimated using field inspections at each cross section following the general guidelines described by Arcement, Jr. and Schneider (1989). Final adjustments to the values were made during the modelling of the reach. Channel " $\mathrm{n}$ " values for the reach ranged from 0.050 to 0.060 .

Normal depth at the exit section (EXITX) was assumed as the starting water surface. This depth was computed by use of the slope-conveyance method outlined in the User's manual for WSPRO (Shearman, 1990). The slope used was $0.0212 \mathrm{ft} / \mathrm{ft}$ which was computed from surveyed thalweg points downstream of the bridge.

The surveyed approach section (APPRO), was used for the modeled section, one bridge length upstream of the upstream face as recommended by Shearman and others (1986). This approach also provides a consistent method for determining scour variables.

The model defaulted to critical depth at the bridge section for the 100-year and 500year discharges. Further analysis showed the water-surface profile passing through critical depth within the constriction. Thus, critical depth was assumed to be a satisfactory solution. 


\section{Bridge Hydraulics Summary}

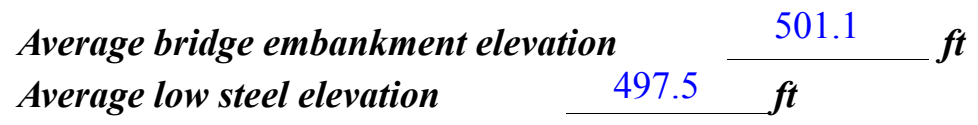

$$
\text { 100-year discharge } \quad 1,650 \quad \mathrm{ft}^{3} / \mathrm{s}
$$

Water-surface elevation in bridge opening $\quad \begin{array}{ll}486.8 \boldsymbol{f t} \\ \end{array}$

Road overtopping? ___ N Discharge over road __

Area of flow in bridge opening $\quad 137 \quad \boldsymbol{f t}^{2}$

Average velocity in bridge opening $\quad 12.1 \quad \mathrm{ft} / \mathrm{s}$

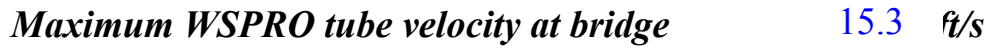

Water-surface elevation at Approach section with bridge 489.9

Water-surface elevation at Approach section without bridge $\quad \overline{48} 8.6$

Amount of backwater caused by bridge $\quad 1.3$ it

500-year discharge $\quad 2,200 \quad \mathrm{ft}^{3} / \mathrm{s}$

Water-surface elevation in bridge opening $\quad 487.9$ ft

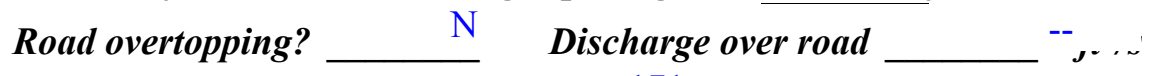

Area of flow in bridge opening $\quad 171 \quad \mathrm{ft}^{2}$

Average velocity in bridge opening $\quad 12.9 \mathrm{ft} / \mathrm{s}$

Maximum WSPRO tube velocity at bridge 16.5 , s

Water-surface elevation at Approach section with bridge 491.2

Water-surface elevation at Approach section without bridge $\quad 489.3$

Amount of backwater caused by bridge 1.9 .

Incipient overtopping discharge ___ -- $f^{3} / \mathrm{s}$

Water-surface elevation in bridge opening $\quad--\quad t$

Area of flow in bridge opening _ -- $\mathrm{ft}^{2}$

Average velocity in bridge opening ___ $\quad \mathrm{ft}_{\mathrm{-}} \mathrm{s}$

Maximum WSPRO tube velocity at bridge _--- $\mathrm{ft} / \mathrm{s}$

Water-surface elevation at Approach section with bridge

Water-surface elevation at Approach section without bridge

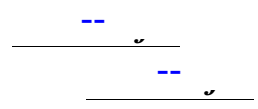

Amount of backwater caused by bridge _ 


\section{Scour Analysis Summary}

\section{Special Conditions or Assumptions Made in Scour Analysis}

Scour depths were computed using the general guidelines described in Hydraulic Engineering Circular 18 (Richardson and others, 1993). Scour depths were calculated assuming an infinite depth of erosive material and a homogeneous particle-size distribution. The results of the scour analysis are presented in tables 1 and 2 and a graph of the scour depths is presented in figure 8.

Contraction scour was computed by use of the clear-water contraction scour equation (Richardson and others, 1993, p. 35, equation 18) for the 100-year and 500-year discharges. For contraction scour computations, the average depth in the contracted section (AREA/ TOPWIDTH) is subtracted from the depth of flow computed by the scour equation (Y2) to determine the actual amount of scour.

Abutment scour was computed by use of the Froehlich equation (Richardson and others, 1993, p. 49, equation 24). The Froehlich equation gives "excessively conservative estimates of scour depths" (Richardson and others, 1993, p. 48). Variables for the Froehlich equation include the Froude number of the flow approaching the embankments, the length of the embankment blocking flow, and the depth of flow approaching the embankment less any roadway overtopping. 


\section{Scour Results}

$$
\text { 100-yr discharge 500-yr discharge }
$$

(Scour depths in feet)

Main channel

Live-bed scour

Clear-water scour

Depth to armoring

Left overbank

Right overbank

Local scour:

Abutment scour

Left abutment

Right abutment

Pier scour

Pier 1

Pier 2

Pier 3
10.0

10.0
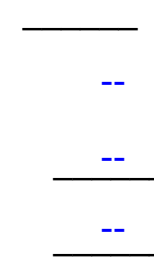

8.7

12.8
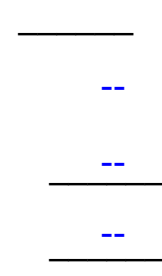

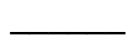

\section{Rock Riprap Sizing}

\section{Abutments:}

\section{Left abutment}

\section{Right abutment}

Piers:

Pier 1

Pier 2
Incipient overtopping 100-yr discharge 500-yrdischarge discharge

1.9

$$
\text { ( } D_{50} \text { in feet) }
$$

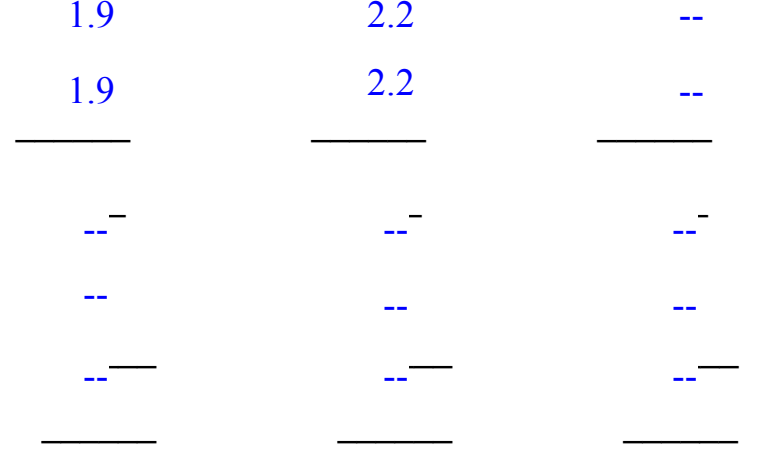




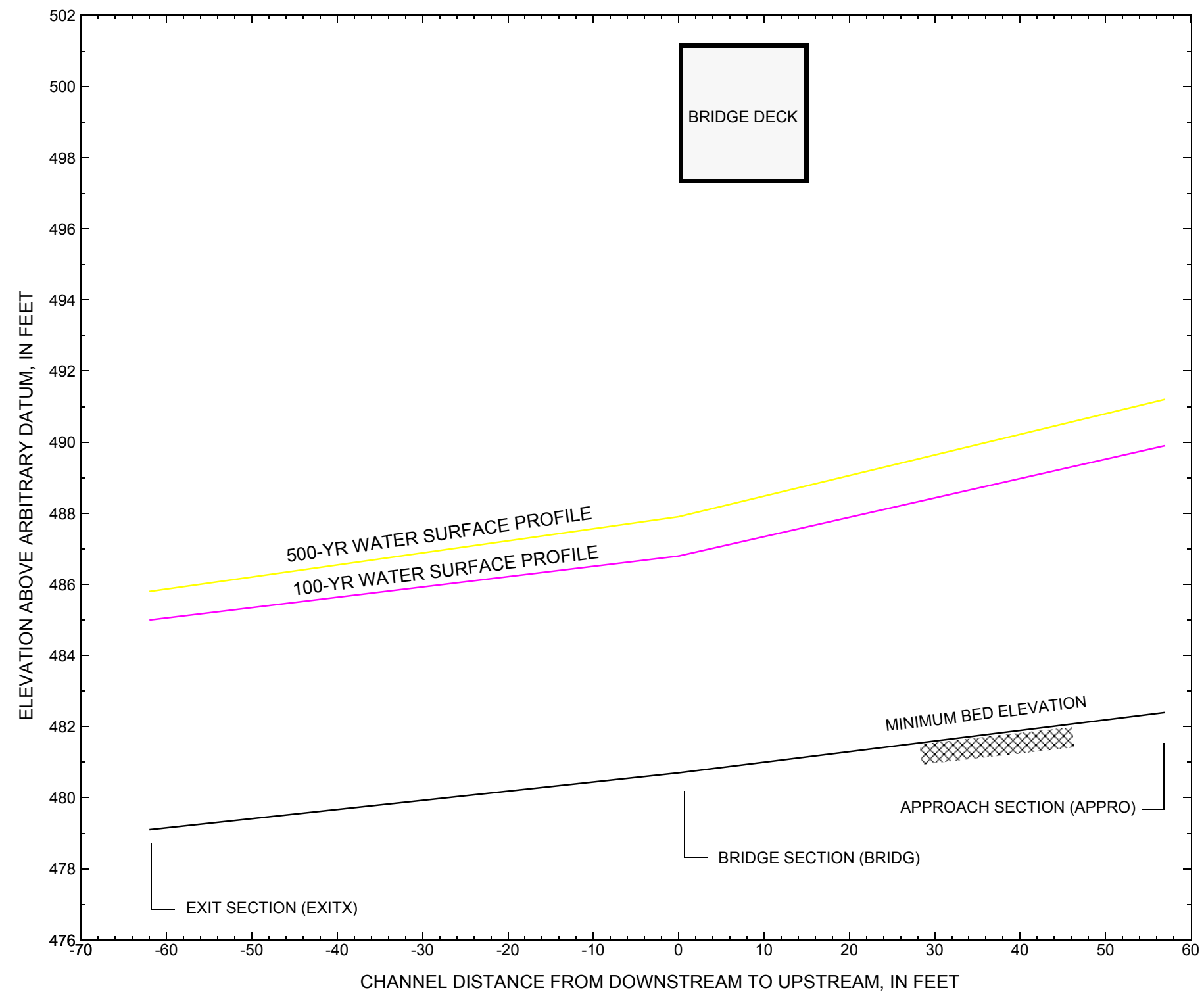

Figure 7. Water-surface profiles for the 100- and 500-yr discharges at structure BETHTH00310033 on town highway 31, crossing Lilliesville Brook, Bethel, Vermont. 


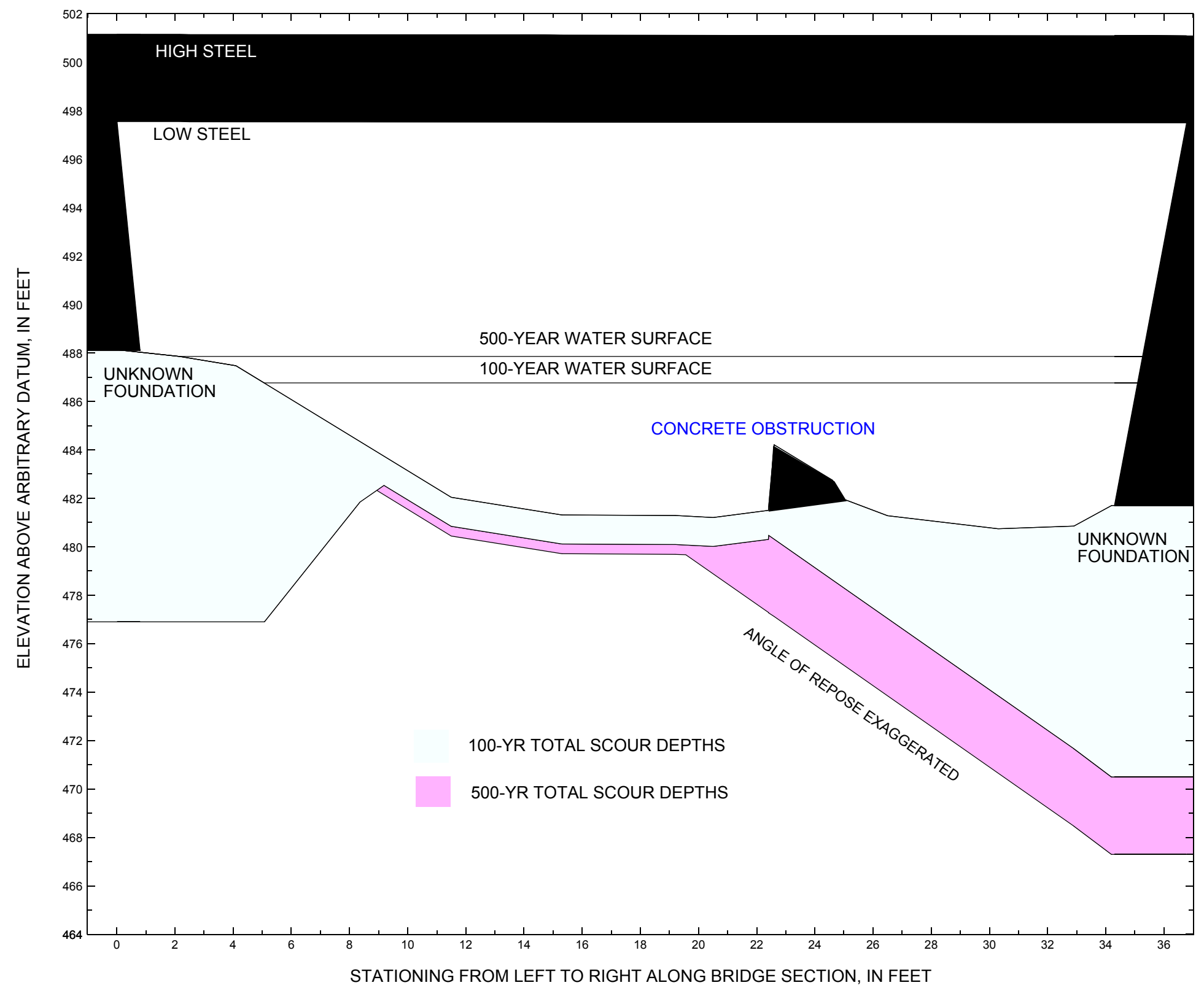

Figure 8. Scour elevations for the 100-yr and 500-yr discharges at structure BETHTH00310033 on town highway 31, crossing Lilliesville Brook, Bethel, Vermont. 
Table 1. Remaining footing/pile depth at abutments for the 100-year discharge at structure BETHTH00310033 on Town Highway 31, crossing Lilliesville Brook, Bethel, Vermont.

[VTAOT, Vermont Agency of Transportation; --,no data]

\begin{tabular}{|c|c|c|c|c|c|c|c|c|c|c|c|}
\hline Description & Station $^{1}$ & $\begin{array}{l}\text { VTAOT } \\
\text { minimum } \\
\text { low-chord } \\
\text { elevation } \\
\text { (feet) }\end{array}$ & $\begin{array}{l}\text { Surveyed } \\
\text { minimum } \\
\text { low-chord } \\
\text { elevation }{ }^{2} \\
\text { (feet) }\end{array}$ & $\begin{array}{c}\text { Bottom of } \\
\text { footing } \\
\text { elevation } \\
\text { (feet) }\end{array}$ & $\begin{array}{c}\text { Channel } \\
\text { elevation at } \\
\text { abutment/ } \\
\text { pier }^{2} \\
\text { (feet) }\end{array}$ & $\begin{array}{l}\text { Contraction } \\
\text { scour depth } \\
\text { (feet) }\end{array}$ & $\begin{array}{l}\text { Abutment } \\
\text { scour } \\
\text { depth } \\
\text { (feet) }\end{array}$ & $\begin{array}{l}\text { Pier } \\
\text { scour } \\
\text { depth } \\
\text { (feet) }\end{array}$ & $\begin{array}{l}\text { Depth of } \\
\text { total scour } \\
\text { (feet) }\end{array}$ & $\begin{array}{c}\text { Elevation of } \\
\text { scour }^{2} \\
\text { (feet) }\end{array}$ & $\begin{array}{c}\text { Remaining } \\
\text { footing/pile } \\
\text { depth } \\
\text { (feet) }\end{array}$ \\
\hline \multicolumn{12}{|c|}{100 -yr. discharge is 1,650 cubic-feet per second } \\
\hline Left abutment & 0.0 & -- & 497.5 & -- & 488.1 & 1.2 & 10.0 & -- & 11.2 & 476.9 & -- \\
\hline Right abutment & 36.8 & -- & 497.5 & -- & 481.7 & 1.2 & 10.0 & -- & 11.2 & 470.5 & -- \\
\hline
\end{tabular}

1. Measured along the face of the most constricting side of the bridge.

2. Arbitrary datum for this study.

Table 2. Remaining footing/pile depth at abutments for the 500-year discharge at structure BETHTH00310033 on Town Highway 31, crossing Lilliesville Brook, Bethel, Vermont.

[VTAOT, Vermont Agency of Transportation; --, no data]

\begin{tabular}{|c|c|c|c|c|c|c|c|c|c|c|c|}
\hline Description & Station $^{1}$ & $\begin{array}{l}\text { VTAOT } \\
\text { minimum } \\
\text { low-chord } \\
\text { elevation } \\
\text { (feet) }\end{array}$ & $\begin{array}{l}\text { Surveyed } \\
\text { minimum } \\
\text { low-chord } \\
\text { elevation } \\
\text { (feet) }\end{array}$ & $\begin{array}{l}\text { Bottom of } \\
\text { footing } \\
\text { elevation } \\
\text { (feet) }\end{array}$ & $\begin{array}{c}\text { Channel } \\
\text { elevation at } \\
\text { abutment/ } \\
\text { pier }^{2} \\
\text { (feet) }\end{array}$ & $\begin{array}{l}\text { Contraction } \\
\text { scour depth } \\
\text { (feet) }\end{array}$ & $\begin{array}{l}\text { Abutment } \\
\text { scour } \\
\text { depth } \\
\text { (feet) }\end{array}$ & $\begin{array}{l}\text { Pier } \\
\text { scour } \\
\text { depth } \\
\text { (feet) }\end{array}$ & $\begin{array}{l}\text { Depth of } \\
\text { total scour } \\
\text { (feet) }\end{array}$ & $\begin{array}{c}\text { Elevation of } \\
\text { scour }^{2} \\
\text { (feet) }\end{array}$ & $\begin{array}{c}\text { Remaining } \\
\text { footing/pile } \\
\text { depth } \\
\text { (feet) }\end{array}$ \\
\hline \multicolumn{12}{|c|}{500 -yr. discharge is 2,200 cubic-feet per second } \\
\hline Left abutment & 0.0 & -- & 497.5 & -- & 488.1 & 1.6 & 8.7 & -- & 10.3 & 477.8 & -- \\
\hline Right abutment & 36.8 & -- & 497.5 & -- & 481.7 & 1.6 & 12.8 & -- & 14.4 & 467.3 & -- \\
\hline
\end{tabular}

1. Measured along the face of the most constricting side of the bridge.

2. Arbitrary datum for this study. 


\section{SELECTED REFERENCES}

Arcement, G.J., Jr., and Schneider, V.R., 1989, Guide for selecting Manning's roughness coefficients for natural channels and flood plains: U.S. Geological Survey Water-Supply Paper 2339, 38 p.

Barnes, H.H., Jr., 1967, Roughness characteristics of natural channels: U.S. Geological Survey Water-Supply Paper 1849, 213 p.

Brown, S.A. and Clyde, E.S., 1989, Design of riprap revetment: Federal Highway Administration Hydraulic Engineering Circular No. 11, Publication FHWA-IP-89-016, 156 p.

Federal Highway Administration, 1983, Runoff estimates for small watersheds and development of sound design: Federal Highway Administration Report FHWA-RD-77-158

Froehlich, D.C., 1989, Local scour at bridge abutments in Ports, M.A., ed., Hydraulic Engineering--Proceedings of the 1989 National Conference on Hydraulic Engineering: New York, American Society of Civil Engineers, p. 13-18.

Hayes, D.C.,1993, Site selection and collection of bridge-scour data in Delaware, Maryland, and Virginia: U.S. Geological Survey Water-Resources Investigation Report 93-4017, 23 p.

Interagency Advisory Committee on Water Data, 1982, Guidelines for determining flood flow frequency: U.S. Geological Survey, Bulletin 17B of the Hydrology Subcommittee, 190 p.

Johnson, C.G. and Tasker, G.D.,1974, Progress report on flood magnitude and frequency of Vermont streams: U.S. Geological Survey Open-File Report 74-130, 37 p.

Laursen, E.M., 1960, Scour at bridge crossings: Journal of the Hydraulics Division, American Society of Civil Engineers, v. 86, no. HY2, p. 39-53.

Potter, W. D., 1957a, Peak rates of runoff in the Adirondack, White Mountains, and Maine woods area, Bureau of Public Roads

Potter, W. D., 1957b, Peak rates of runoff in the New England Hill and Lowland area, Bureau of Public Roads

Richardson, E.V., Harrison, L.J., Richardson, J.R., and Davis, S.R., 1993, Evaluating scour at bridges: Federal Highway Administration Hydraulic Engineering Circular No. 18, Publication FHWA-IP-90-017, 131 p.

Richardson, E.V., Simons, D.B., and Julien, P.Y., 1990, Highways in the river environment: Federal Highway Administration Publication FHWA-HI-90-016.

Ritter, D.F., 1984, Process Geomorphology: W.C. Brown Co., Debuque, Iowa, 603 p.

Shearman, J.O., 1990, User's manual for WSPRO--a computer model for water surface profile computations: Federal Highway Administration Publication FHWA-IP-89-027, 187 p.

Shearman, J.O., Kirby, W.H., Schneider, V.R., and Flippo, H.N., 1986, Bridge waterways analysis model; research report: Federal Highway Administration Publication FHWA-RD-86-108, 112 p.

Talbot, A.N., 1887, The determination of water-way for bridges and culverts.

U.S. Department of Transportation, 1993, Stream stability and scour at highway bridges, Participant Workbook: Federal Highway Administration Publication FHWA HI-91-011.

U.S. Geological Survey, 1980, Bethel, Vermont 7.5 Minute Series quadrangle map: U.S. Geological Survey Topographic Maps, Scale 1:24,000. 


\section{APPENDIX A: \\ WSPRO INPUT FILE}




\section{WSPRO INPUT FILE}

Q

SK

*

J3

*

XS EXITX -62

GR

GR

GR

GR

$\mathrm{N}$

*

*

B

GR

GR

GR

GR

GR

*

CD

$\mathrm{N}$

*

$\mathrm{X}$

*

GR

GR

GR

GR

*

AS APPRO

*

GR

GR

GR

GR

N

HP 1 BRIDG

HP 2 BRIDG

HP 1 APPRO

HP 2 APPRO

*

HP 1 BRIDG

HP 2 BRIDG

HP 1 APPRO

FULLV

BRIDG

(1)

0.050

RDWAY$$
115.6
$$

$$
57
$$

U.S. GEOLOGICAL SURVEY WSPRO INPUT FILE beth033.wsp CREATED ON 04-DEC-95 FOR BRIDGE BETHTH00310033 USING FILE beth033.dca Hydraulic analysis for Bethel bridge 33 by MAI

$\begin{array}{ll}1650.0, & 2200.0 \\ 0.0212 & 0.0212\end{array}$

$\begin{array}{lllllllllllllllllllll}6 & 29 & 30 & 552 & 553 & 551 & 5 & 16 & 17 & 13 & 3 & * & 15 & 14 & 23 & 21 & 11 & 12 & 4 & 7 & 3\end{array}$

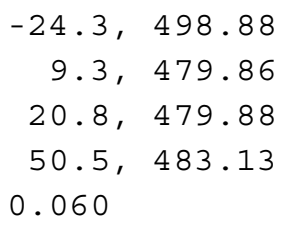
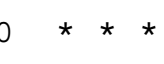

0.0331

$$
\begin{array}{r}
0.0,497.52 \\
11.5,482.04 \\
22.4,481.50 \\
26.5,481.28 \\
36.8,497.50
\end{array}
$$

$130.1 * *$

$$
\begin{array}{rr}
-112.9, & 511.01 \\
-9.9, & 500.91 \\
37.6, & 501.06 \\
115.6, & 500.53
\end{array}
$$

15.0

$$
0.8
$$$$
15.3,481.31
$$$$
22.6,484.21
$$$$
30.3,480.74
$$$$
0.0,497.52
$$$$
30.0 \quad 21.9
$$$$
-16.0,499.75
$$$$
8.2,483.30
$$$$
22.2,483.38
$$$$
41.2,487.09
$$$$
0.060
$$

486.761486 .76

486.76 * 41650

489.911489 .91

489.91 * 1650

487.861487 .86

487.86 * 2200

491.191491 .19

$\begin{array}{rr}0.0,484.75 & 6.8,480.56 \\ 16.2,479.13 & 20.3,479.32 \\ 36.1,482.01 & 42.7,482.35 \\ 58.6,487.30 & 71.2,497.93\end{array}$

$4.1,487.47$

$11.5,482.04$

$20.5,481.21$

$25.0,481.96$

$34.2,481.70$

$32.9,480.85$

74.70$$
-2.3,488.16
$$$$
11.5,482.47
$$$$
22.2,483.38
$$

$52.2,486.56$

$$
\begin{array}{rrrr}
-95.6,504.16 & -73.5,502.75 & -37.4,501.61 \\
-1.3,501.14 & 0.0,501.18 & 19.2,501.10 \\
38.8,501.07 & 90.4,500.17 & 103.8,499.67 \\
134.4,500.75 & 151.8,504.93 & &
\end{array}
$$

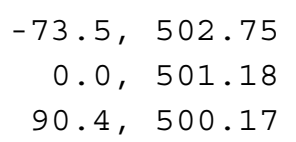




\section{APPENDIX B: \\ WSPRO OUTPUT FILE}


WSPRO OUTPUT FILE

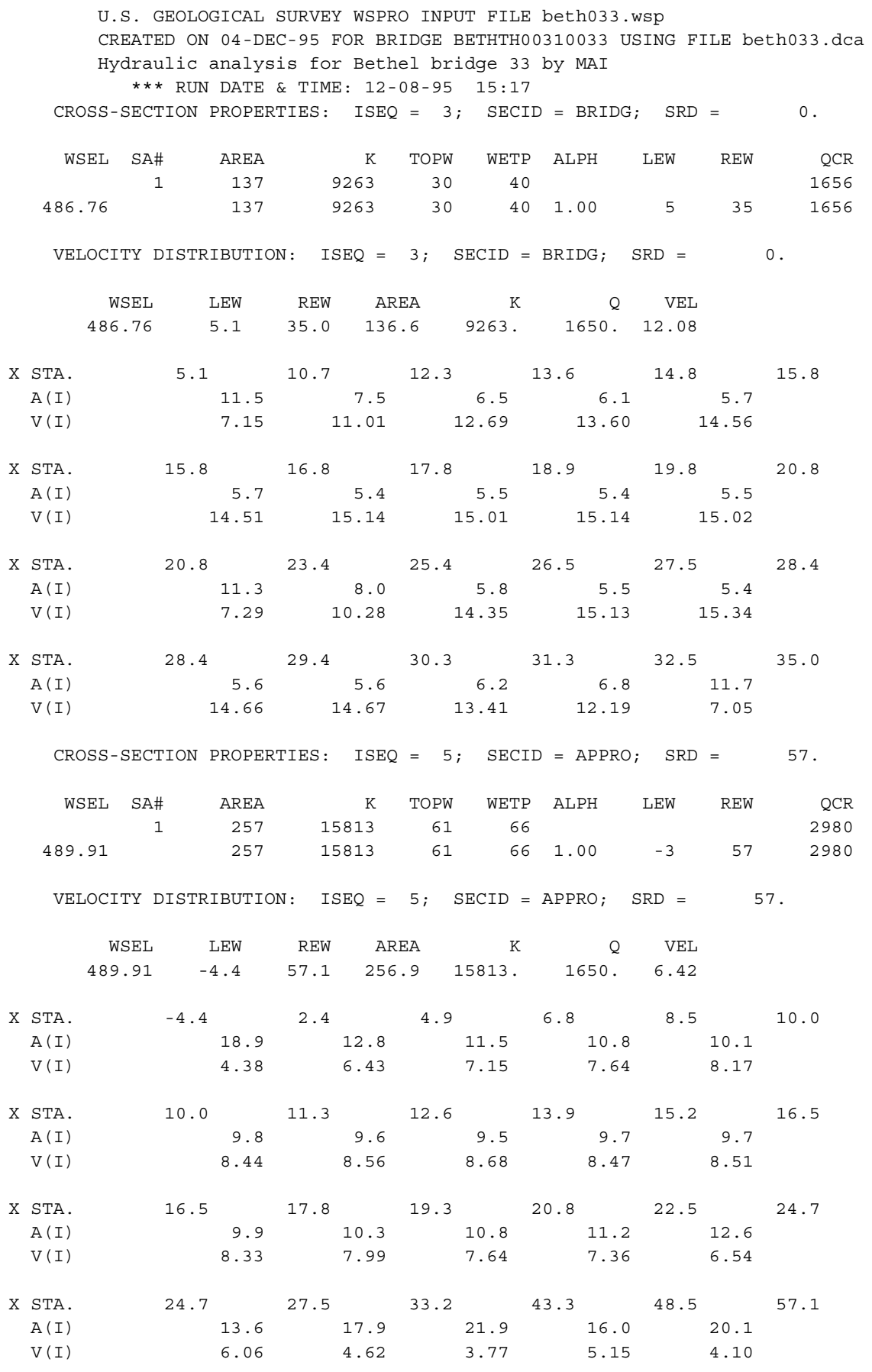


WSPRO OUTPUT FILE (continued)

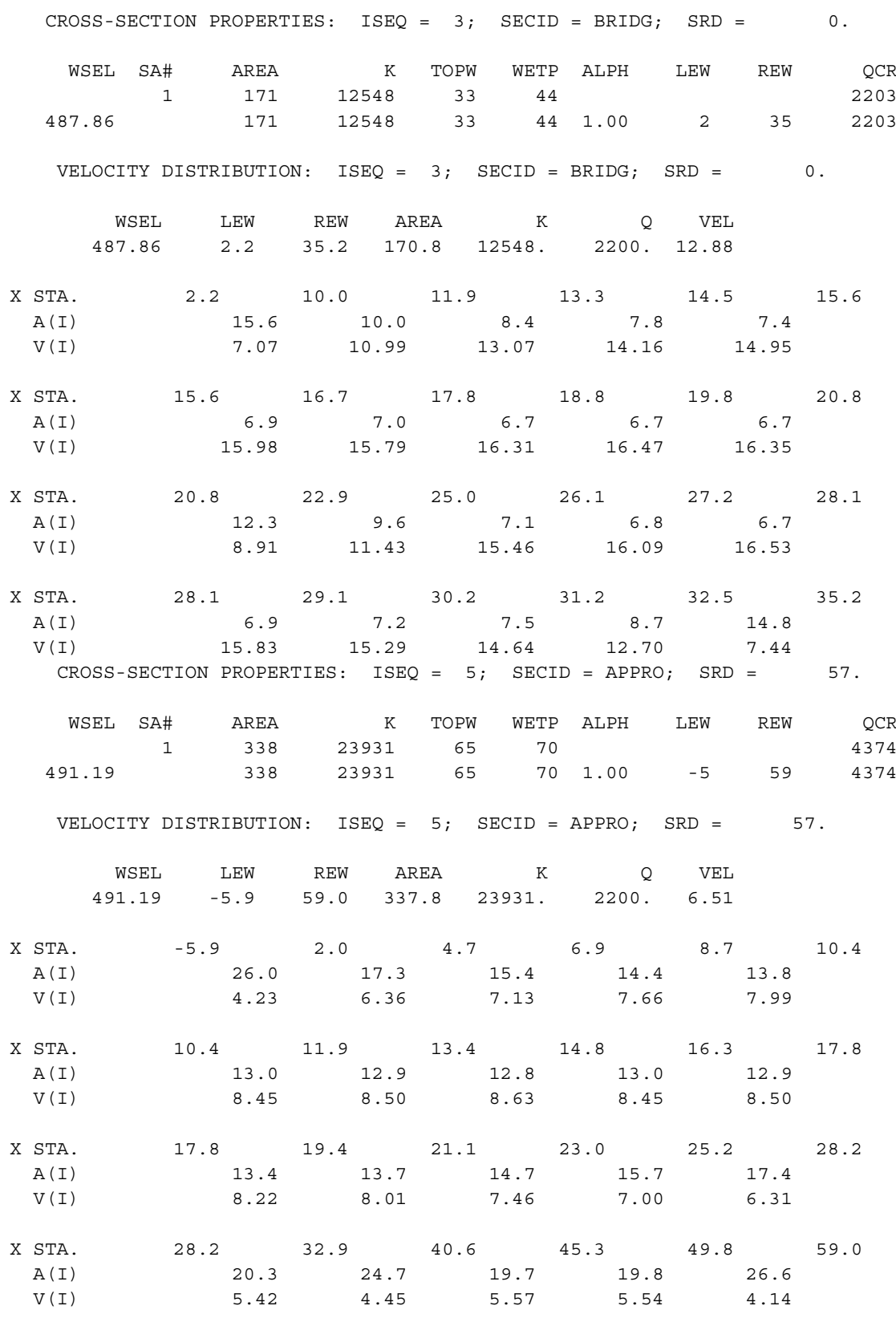


WSPRO OUTPUT FILE (continued)

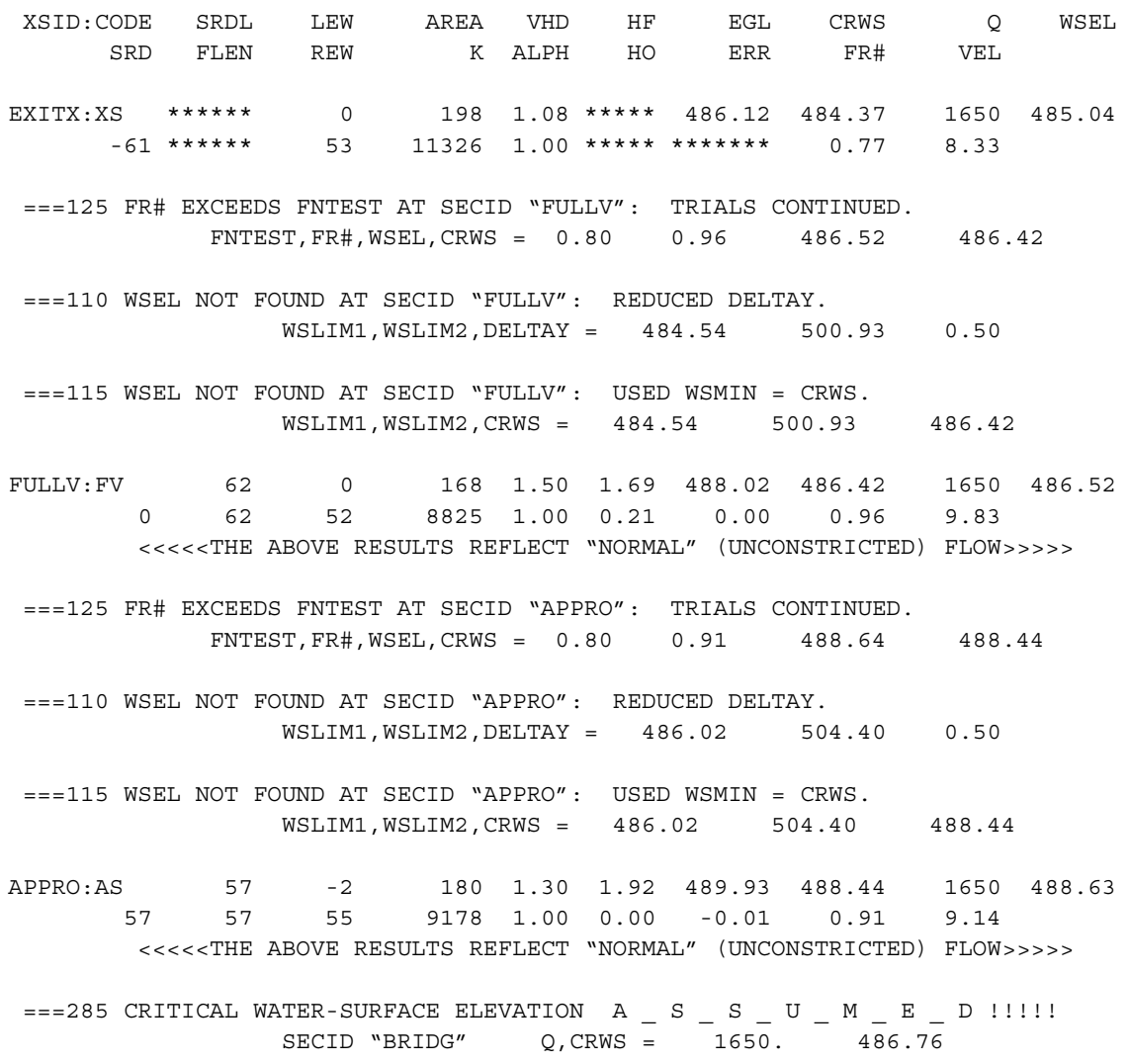

SECOND USER DEFINED TABLE.

\begin{tabular}{|c|c|c|c|c|c|c|c|c|c|}
\hline XSID : CODE & CRWS & FR\# & YMIN & YMAX & $\mathrm{HF}$ & $\mathrm{HO}$ & VHD & EGL & WSEL \\
\hline EXITX:XS & 484.37 & 0.77 & 479.13 & $498.88 *$ & $\star \star \star *$ & $\star * *$ & 1.08 & 486.12 & 485.04 \\
\hline FULLV : FV & 486.42 & 0.96 & 481.18 & 500.93 & 1.69 & 0.21 & 1.50 & 488.02 & 486.52 \\
\hline BRIDG : BR & 486.76 & 1.00 & 480.74 & 497.52 * & $\star * \star \star \star \star *$ & 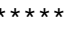 & 2.27 & 489.03 & 486.76 \\
\hline RDWAY : RG & 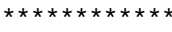 & $\star * \star \star *$ & 499.67 & $511.01 *$ & 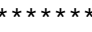 & 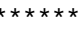 & $\star \star \star \star \star *$ & 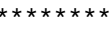 & 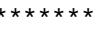 \\
\hline APPRO : AS & 488.44 & 0.55 & 482.45 & 504.40 & 0.56 & 0.96 & 0.64 & 490.55 & 489.91 \\
\hline
\end{tabular}


WSPRO OUTPUT FILE (continued)

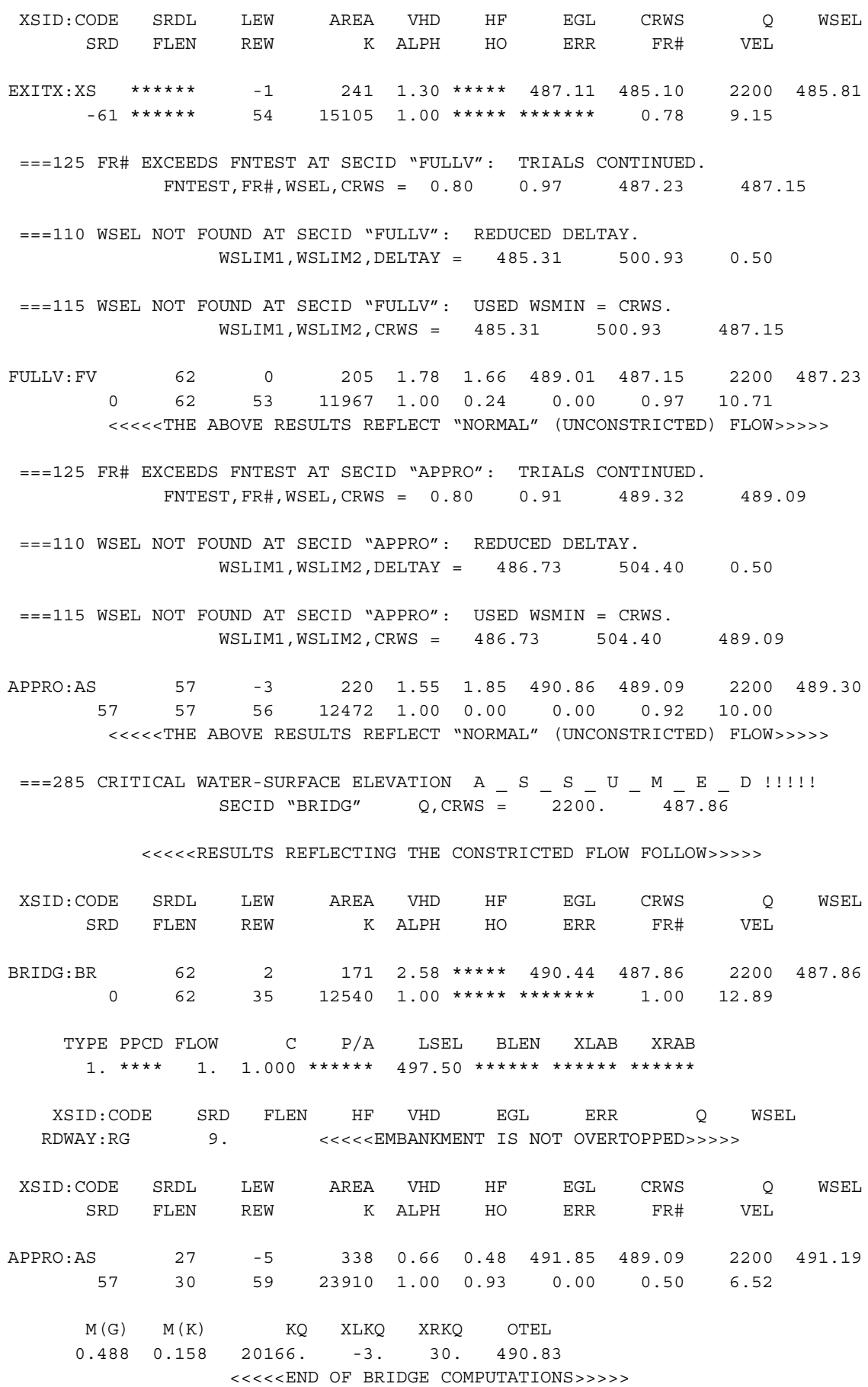




\section{APPENDIX C:}

\section{BED-MATERIAL PARTICAL-SIZE DISTRIBUTION}




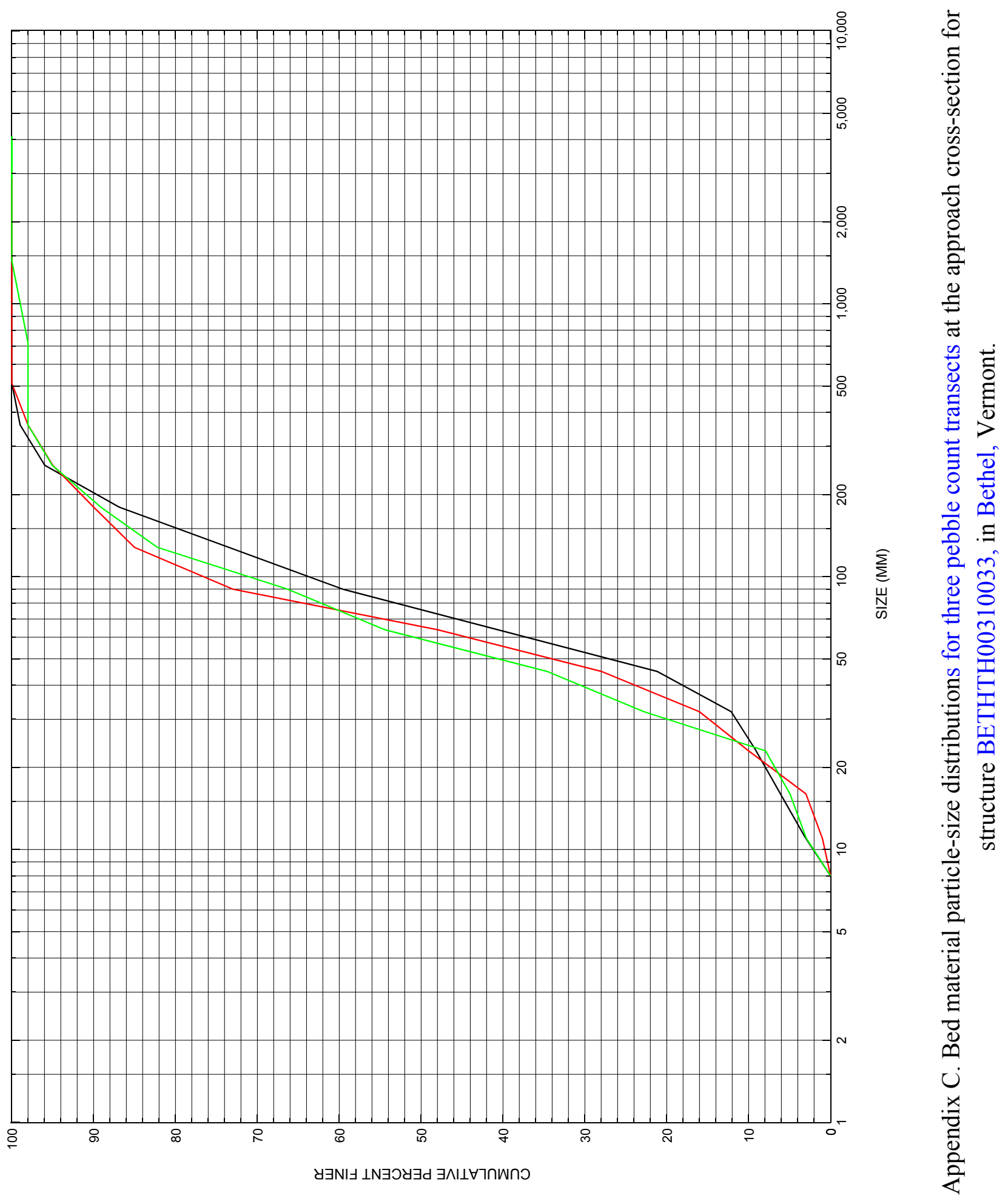




\section{APPENDIX D: \\ HISTORICAL DATA FORM}

